\title{
Differences in Learning Methods Start With a Question and Question Student Have Against Social Learning Results Proclamation History Indonesian Independence
}

\section{Sriawan Asri, Risky Dwiprabowo}

STKIP Kusuma Negara

sriawan45@gmail.com

\section{Article History}

accepted 24/09/2019

\begin{abstract}
This study aims to determine whether or not there are differences in the results of social studies learning material on the history of the proclamation of Indonesian independence of students taught by learning methods. Learning Starts With A Question and Question Student Have. This study uses a quantitative method with the type of approach "quasi-experimental" and "experimental design posttest-only control group" research sample consisted of 30 students in the experimental class I and 30 students in experiment II. This sampling uses a sample cluster. Based on the calculation results obtained an average of X1 66.3 and an average value of $X 2$ 93.5 after which the t-test was calculated, then the t-count was obtained at 9.03 with a dk of 58 then obtained a ttable with a significance level of 2.02. Because tcount> ttable, it can be concluded that $\mathrm{HO}$ is rejected and $\mathrm{H} 1$ is accepted, it can be concluded that there are significant differences in the use of learning strategies Learning Starts With A Question And Question Student Have.
\end{abstract}

Keywords: Learning strategies Learning Starts With A Question, Question Student Have learning strategies, social studies.

\begin{abstract}
Abstrak
Penelitian ini bertujuan untuk mengetahui terdapat atau tidaknya perbedaan hasil belajar IPS materi sejarah proklamasi kemerdekaan indonesia peserta didik yang diajar dengan metode pembelajaran Learning Starts With A Question Dan Question Student Have. Penelitian ini menggunakan metode kuantitatif dengan jenis pendekatan "quasi eksperimen"dan "desain eksperimen posttest-only control group" sampel penelitian terdiri dari 30 peserta didik pada kelas eksperimen ke I dan 30 peserta didik pada eksperimen ke II. Pengambilan sampel ini menggunakan cluster sampel Berdasarkan hasil perhitungan di peroleh rata-rata $X_{1}$ 66,3 dan nilai rata-rata $X_{2} 93,5$ setelah itu dilakukan perhitungan uji-t, lalu $t$ hitung diperoleh sebesar 9.03 dengan dk sebesar 58 maka di peroleh tabel dengan taraf signifikansi sebesar 2,02. Karena thitung $>$ ttabel , maka dapat disimpulakan bahwa $\mathrm{H}_{0}$ ditolak dan $\mathrm{H}_{1}$ diterima, maka dapat disimpulkan bahwa terdapat perbedaan yang signifikan penggunakan strategi pembelajaran Learning Starts With A Question Dan Question Student Have.
\end{abstract}

Kata kunci: Strategi pembelajaran Learning Starts With A Question, strategi pembelajaran Question Student Have, hasil belajar IPS.

Social, Humanities, and Education Studies (SHEs): Conference Series https://jurnal.uns.ac.id/shes 


\section{PENDAHULUAN}

Pendidikan merupakan salah satu faktor utama untuk mewujudkan masyarakat yang berkualitas. Pendidikan adalah suatu lembaga pendidikan yang telah tersusun dan terencana secara formal oleh pemerintahan untuk mewujudkan suatu hasil dalam pembelajaran pengetahuan, keterampilan dan kebiasaan orang yang diturunkan dari generasi ke generasi selanjutnya dengan melalui pengajaran, pelatihan, dan penelitian. Oleh karena itu, pemerintahan Indonesia selalu berusaha meningkatkan kualitas pendidikan walaupun hasilnya belum memenuhi harapan. Salah satu cerminan kualitas pendidikan di sekolah adalah hasil belajar yang di capai oleh peserta didik di sekolah tersebut. Dengan demikian hasil belajar peserta didik pada mata pelajaran tertentu merupakan salah satu indikator kualitas pendidikan di sekolah yang bersangkutan.

Dalam perkembangan IPS kelas tinggi ada beberapa kesulitan yang dialami oleh peserta didik, salah satunya peserta didik kurang dapat mengembangkan nilai dan sikap dalam kehidupan sehari-hari di karenakan pengajaran IPS dilaksanakan dengan waktu yang terbatas, sehingga tidak mungkin dapat memperkenalkan seluruh nilai-nilai kehidupan manusia kepada peserta didik. Oleh karena itu nilai-nilai yang akan ditanamkan kepada peserta didik merupakan nilai-nilai yang pokok dan mendasar bagi kehidupan manusia. Dalam prakteknya guru hanya ceramah dan terpaku dengan buku sehingga pelajaran IPS dianggap pelajaran yang membosankan, tidak menarik dan sulit dipahami. Selain itu partisipasi peserta didik dalam proses pembelajaran IPS kurang, padahal partisipasi peserta didik sangat penting. Hal ini di karenakan kurangnya metode pembelajaran dalam pelajaran IPS dan mengakibatkan hasil belajar mata pelajaran IPS yang diperoleh peserta didik rendah.

Berdasarkan hasil wawancara penelitian dengan guru kelas ( Ibu Destis S.Pd) yang mengajar mata pelajaran IPS kelas V Sekolah Dasar Negeri Mampir Cileungsi diperoleh bahwa nilai ujian pesrta didik pada mata pelajaran IPS lebih rendah dibanding dengan mata pelajaran yang lain. Lebih dari $50 \%$ peserta didik tidak dapat mencapai Kriteria Ketuntasan Minimal (KKM) yang telah ditetapkan. Adapan nilai Kriteria Ketuntasan Minimal (KKM) yang tersebut adalah 70. Proses pembelajaran yang dilakukan guru saat itu cenderung pada pencapaian target materi kurikulum. Terbukti dari kegiatan pembelajaran di dalam kelas yang selalu didominasi oleh guru. Dalam penyampaian materi, biasanya peserta didik belajar dengan mendengan, menyimak, melihat, meniru apa yang diinformasikan oleh guru sebagai fasilitor di depan kelas.

Hasil Belajar Menurut Dimyati dan Mudjiono (2009:3) merupakan hasil dari suatu interaksi tindak belajar dan mengajar. Sedangkan menurut Kompri (2016:218) belajar berarti usaha mengubah tingkah laku. Jadi Belajar akan membawa suatu perubahan pada individu-individu yang melakukan kegiatan belajar. Perubahan tidak hanya berkaitan dengan penambahan ilmu pengetahuan tetapi juga dalam bentuk kecakapan, keterampilan, sikap, pengertian harga diri, minat, watak, dan penyesuaian diri. Dengan demikian dapat disimpulkan bahwa belajar itu sebagai rangkaian kegiatan jiwa raga, psiko-fisik untuk meenuju kearah perkembangan pribadi manusia seutuhnya.

Ahmad Susanto (2014:2) pembelajaran pendidikan IPS memiliki tujuan yang sangat agung dan mulia, yaitu untuk memahami dan mengembangkan pengetahuan, nilai, sikap, keterampilan, sosial, kewarganegaraan, fakta, peristiwa, konsep, dan generalisasi serta mampu merefleksikan dalam kehidupan masyarakat, bangsa, dan negara. Tujuan tersebut sudah jelas dan tegas untuk memberikan bekal bagi peserta didik yang begitu lengkap dan paripurna. Apabila guru mampu menerapkan dan meneladani pada peserta didiknya akan dapat menjadikan peserta 
didik sebagai manusia yang paripurna, dalam arti manusia yang memiliki jiwa sosial tinggi, yang memiliki kepedulian yang tinggi kepada manusia lainnya.

Ilmu pengetahuan sosial merupakan intergrasi dari berbagai cabag ilmu-ilmu sosial dan humaniora, yaitu: sosiaologi, sejarah, geografi, ekonomi, politik, hukum, dan budaya. Ilmu pengetahuan sosial dirumuskan atas dasar realitas dan fenomena sosial yang mewujudkan satu pendekatan interdisipliner dari aspek dan cabangcabang ilmu sosial di atas. Dari pengertian tersebut dapat di sintesakan maka pembelajaran IPS harus mencangkup ke mandirian peserta didik, dan kesadaran lingkungan peserta didik, agar lebih mengembangkan wawasan untuk menjadi warga negara yang memiliki pengetahuan, nilai sikap, dan keterampilan yang memadai untuk berperan serta dalam kehidupan demokrasi.

Muhamad Afandi (2018:46) metode learning start with a question (LSQ) adalah metode pembelajaran yang digunakan untuk meningkatkan keaktifan peserta didik dalam pembelajaran di kelas. Keaktifan peserta didik dalam proses pembelajaran akan menciptakan situasi belajar aktif. Belajar aktif sangat di perlukan peserta didik untuk memperoleh hasil belajar yang maksimal.Lerning star with a question (LSQ) merupakan pembelajaran aktif bertanya. Pertanyaan yang di buat sendiri oleh peserta didik memiliki kontribusi dalam pembelajaran yang bermakna karena pada saat mengajukan pertanyaan, peserta didik sedang mengkontruk pengetahuan mereka sendiri. Metode learning start with a question adalah metode yang cukup relevan memberikan inovasi terbaru untuk proses belajar mengajar di sekolah dasar, menjadikan peserta didik aktiv dan cepat memahami materi yang di ajarkan, peserta didik lebih mudah mengemukakan jawaban yang peserta didik sendiri dapatkan.

Ibid (hlm.58) Metode question studen have di kembangkan untuk melatih peserta didik agar memiliki kemampuan dan keterampilan bertanya. Pembelajaran dengan metode ini diawali dengan membagi kelas menjadi 4 kelompok. Jumlah kelompok sebaiknya di sesuaikan dengan jumlah peserta didik.Question student have ini merupakan cara yang mudah untuk mempelajari keinginan dan harapan peserta didik. Cara ini menggunakan sebuah teknik untuk mendapatkan partisipasi melalui tulisan daripada percakapan.

Peningkatan kualitas sumber daya manusia dapat di lakukan antara lain melalui jalur pendidikan. Pencapaian tujuan pendidikan sangat bergantung pada berbagai faktor, diantaranya adalah kemampuan peserta didik untuk menyerap dan memahami materi pelajaran yang disampaikan oleh guru dalam kegiatan pembelajaran yang juga terkait dengan faktor lainnya. Kegiatan pembelajaran sebagai proses komunikasi edukatif antara guru dengan peserta didik atau peserta didik tidak selalu dengan yang diharapkan. Ini disebabkan karena tidak semua pesan disampaikan guru berupa materi pelajaran dapat diterima oleh peserta didik seperti yang di harapkan oleh guru. Keberhasilan proses kegiatan belajar mengajar pada pembelajaran IPS dapat diukur dari keberhasilan belajar peserta didik. Dengan metode pembelajaran yang sesuai peserta didik dapat mencapai prestasi belajar yang tinggi. Metode pembelajaran learining staert question adalah metode yang dapat di gunakam untuk meningkatkan proses pembelajaran peserta didik dan dapat disesuaikan dengan tujuan yang ingin dicapai oleh pembelajaran pada berbagai mata pelajaran. Khususnya pencapaian tujuan yaitu meliputi aspek: kemampuam berkomunikasi (bertanya), kemampuan mengemukakakn pendapat, kemampuan mengenal masalah, kemampuan menuliskan pendapat-pendapatnya (kelompok) setelah melakukan pengamatan, kemampuan menyimpulkan, dan lain-lain. Sedangkan metode pembelajaran question studen have adalah teknik untuk mempelajari keinginan dan harapan peserta didik guna memaksimalkan potensi yang dimilikinya. 


\section{METODE}

Penelitian ini bertujuan untuk membuktikan adanya perbedaan yang signifikan antara metode learning start with a question dan metode qeuastion student have pada hasil belajar IPS materi sejarah proklamasi kemerdekaan indonesia kelas IV semester 2 di Sekolah Dasar Negeri Mampir Cileungsi. Penelitian ini dilaksanakan di Sekolah Dasar Negeri Mampir Cileungsi, Jalan Raya Mampir Rt 07, Rw 04, Desa Mampir, Kecamatan Cileungsi, penelitian ini dilaksanakan pada tanggal 10 April 2019 sampai 10 Mei 2019 tahun pelajaran 2018/2019.

Metode penelitian yang di gunakan dalam penelitian ini yaitu metode kuantitatif tipe quasi eksperimen design. Quasi experimental design merupakan pengembangan dari true experimental design. Rancangan penelitian ini adalah dengan bentuk post test only control group design yaitu metode penelitan yang meneliti dua kelas (kelompok) yang masing-masing dipilih secara random (R), kemudian di beri post tes dan hasilnya dibandingkan. Dua kelas tersebut yaitu kelas eksperimen 1 dan kelas ekperimen 2. Pada kelas ekperimen 1 penyajian materi pembelajaran menggunakan metode learning start with question, sedangkan pada kelas eksperimen 2, peyajiannya menggunakan metode question studen have. Teknik pengambilan sampel menggunakan teknik cluster sampling.

\section{HASIL DAN PEMBAHASAN}

\section{Hasil Belajar IPS Materi Proklamasi Kemerdekaan Indonesia Peserta Didik Yang Di Ajarkan Dengan Menggunakan Metode Learning Start With A Question}

Dari data diperoleh melalui penyebaran instrumen yang diisi oleh peserta didik yang diajarkan menggunakan metode Learning Start With A Question di dapat nilai minimum sebesar 79 sedangkan nilai maksimum sebesar 100 median sebesar 93.5 modus sebesar 89.34 varian sebesar 41.74 dan simpangan baku sebesar 6.46 adapun hasil tabel distribusi frekuensi kelompok ini sebagai berikut:

Tabel 1 Distribusi Frekuensi Hasil Belajar IPS Materi Sejarah Proklamasi Kemerdekaan Indonesia Metode Learning Start With A Question

\begin{tabular}{|c|c|c|c|c|c|c|}
\hline Kelas & nilai tengah & $\mathrm{Fi}$ & (fi.xi) & & $\mathrm{Xi}^{2}$ & $\begin{array}{l}\text { (fi.xi 2 } \\
\text { interval (i) }\end{array}$ \\
\hline $50-54$ & 52 & 1 & 52 & 1 & 2704 & 2704 \\
\hline $55-59$ & 57 & 5 & 285 & 6 & 3249 & 16245 \\
\hline $60-64$ & 62 & 5 & 310 & 11 & 3844 & 19220 \\
\hline $65-69$ & 67 & 8 & 536 & 19 & 4489 & 35912 \\
\hline $70-74$ & 72 & 10 & 720 & 29 & 5184 & 51840 \\
\hline $75-79$ & 77 & 1 & 77 & 30 & 5929 & 5929 \\
\hline & 387 & 30 & 1980 & & 25399 & 131850 \\
\hline
\end{tabular}

\section{Hasil Belajar IPS Materi Proklamasi Kemerdekaan Indonesia Peserta Didik Yang Di Ajarkan Dengan Menggunakan Metode Question Student Have}

Dari data diperoleh melalui penyebaran instrumen yang diisi oleh peserta didik yang diajarkan menggunakan metode Question Student Have di dapat nilai minimum sebesar 50 sedangkan nilai maksimum sebesar 72 median sebesar 66.3 modus 
sebesar 66.34 varian sebesar 40.34 dan simpangan baku sebesar 6.35 adapun hasil tabel distribusi frekuensi kelompok ini.

Tabel 2 Distribusi Frekuensi Hasil Belajar IPS Materi Sejarah Proklamasi Kemerdekaan Indonesia Metode Question Stident Have

\begin{tabular}{|c|c|c|c|c|c|c|}
\hline $\begin{array}{c}\text { kelas } \\
\text { interval (i) }\end{array}$ & $\begin{array}{c}\text { nilai tengah } \\
(\mathrm{Xi}) \\
\end{array}$ & $\mathrm{Fi}$ & (fi.xi) & $\mathrm{fk}$ & $\mathrm{Xi}^{2}$ & $(\text { fi.xi })^{2}$ \\
\hline $50-54$ & 52 & 1 & 52 & 1 & 2704 & 2704 \\
\hline $55-59$ & 57 & 5 & 285 & 6 & 3249 & 16245 \\
\hline $60-64$ & 62 & 5 & 310 & 11 & 3844 & 19220 \\
\hline $65-69$ & 67 & 8 & 536 & 19 & 4489 & 35912 \\
\hline $70-74$ & 72 & 10 & 720 & 29 & 5184 & 51840 \\
\hline $75-79$ & 77 & 1 & 77 & 30 & 5929 & 5929 \\
\hline & 387 & 30 & 1980 & & 25399 & 131850 \\
\hline
\end{tabular}

Dari data hasil penelitian maka di dapat simpulkan bahwa bisa digunakan sebagai acuan bagi guru kelas dalam menerapkan metode pembelajaran sesuai dengan kebutuhan siswa yang terkait dengan memaksimalkan hasil belajar IPS materi sejarah proklamasi kemerdekaan indonesia. Penerapan metode pembelajaran Learning Starts With A Question dengan metode pembelajaran Question student Have memiliki perbedaan yang cukup signifikan terhadap hasil belajar IPS materi sejarah proklamasi kemerdekaan indonesia. Penerapan metode pembelajaran aktif tipe Learning Starts With A Question dan metode pembelajaran Question Student Have dalam memaksimalkan hasil belajar IPS siswa memperoleh tanggapan positif dari siswa dan guru.

Metode pembelajaran ini mempunyai potensi untuk dikembangkan agar siswa dapat meningkatkan keterampilan dalam bekerja sama dalam kelompok belajar, meningkatkan kemampuan siswa dalam menyampaikan ide atau gagasan, bertanggung jawab pada aktifitas dalam proses pembelajaran, menjadikan pembelajaran IPS materi sejarah proklamasi kemerdekaan indonesia yang menyenangkan dan bermakna bagi siswa. Pembelajaran IPS materi sejarah proklamasi kemerdekaan indonesia dengan metode pembelajaran aktif tipe Learning Stars With A Question dan metode pembelajaran Question Student Have mampu membuat siswa menjadi aktif, termotivasi dan siswa juga lebih mudah memahami materi pembelajaran IPS.

\section{SIMPULAN}

Setelah diadakannya program parenting yang dlaksanakan di Desa Karangtanjung dapat disimpulkan bahwa terdapat pengaruh program parenting terhadap pengetahuan dan sikap orang tua dalam pemenuhan kebutuhan dasar anak. Dengan adanya program parenting dapat (1) Meningkatkan pengetahuan orang tua akan pola asuh yang benar sesuai tahap perkembangan anak sebesar yaitu $12 \%$ yang diperoleh dari hasil posttest (2) Meningkatkan kepedulian orang tua terhadap asupan gizi seimbang yang penting untuk tumbuh kembang anak. (3) Meningkatkan pemahaman orang tua mengenai pentingnya keikutsertaan orang tua dalam proses belajar anak di rumah. 


\section{DAFTAR PUSTAKA}

Afandi, Muhamad. (2014). Jurnal Pendidikan dan Pembelajaran Dasar. Volume 5 Nomor 1.

Dimyati, \& Mudjiono. (2009). Belajar dan Pembelajaran. Jakarta: Rineka Cipta.

Helmawati. 2016. Pendidikan Keluarga. Bandung: PT Remaja Rosdakarya.

Rustam, Ahmad. (2016). Dasar-Dasar Statistic Kolala: Penerbit Putri Yoland.

Sugiyono. (2012). MetodologiPenelitian Kuantitatif Kualitatif dan R\&D. Bandung, Alfabeta.

Suprijono, Agus. (2009). Cooperative Learning Teori dan Aplikasi PAIKEM. Yogyakarta : Pustaka Pelajar.

Suprijono, Agus. (2016). Medel-Model Pembelajaran Emansipatoris, Yogyakarta : Pustaka Pelajar.

Susanto, Ahmad. (2014). Pengembangan Pembelajran IPS Di Sekolah Dasar. Jakarta: Prenadamedia Group

Sugiono. (2016). Statistika Untuk Penelitian. Bandung: Alfabet . 